UNIVERSITY

OF DEBRECEN

FACULTY OF

HeAlth

NYÍREGYHÁZA

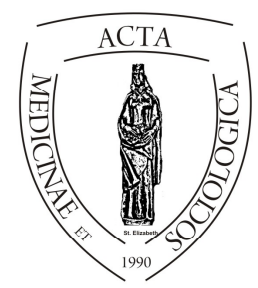

ACTA

MedSoc

Volume 8.

2017

\title{
Health status of pregnant women in Szabolcs-Szatmár-Bereg county of Hungary between 2010 and 2012
}

Ágota Moravcsik-Kornyicki ${ }^{1}$, Zsigmond Kósa ${ }^{1}$, Erdei Renáta Jávorné $^{1}$, Anikó Gyulai ${ }^{1}$, Sándor János ${ }^{2}$, Karolina Kósa ${ }^{3}$

${ }^{1}$ University of Debrecen Faculty of Health, Institute of Health Sciences, Department of Health Methodology and Public Health, Nyíregyháza, Hungary

${ }^{2}$ University of Debrecen Faculty of Public Health, Department of Preventive Medicine

Division of Biostatistics and Epidemiology, Debrecen, Hungary

${ }^{3}$ University of Debrecen Faculty of Public Health, Institute of Behavioral

Sciences, Debrecen, Hungary

DOI: $10.19055 / \mathrm{ams} .2017 .8 / 24 / 2$

\begin{abstract}
.
Introduction: The Hungarian population decreases continuously since 1981, but does not show improving trend the premature babies proportion and the low weight gain in new-born baby's proportion in Hungary. The childhood health has an impact on the adult health status, moreover has an effect on its quality. It is necessary to take it into consid-eration to the planning of the interventions. Knowing this result the pregnant women's care will be even more important.
\end{abstract}

Aim. Our objective was to describe changes in the health status of pregnant women at the national and Szabolcs-Szatmár-Bereg county level during the period of 2010-2012. Method. Data were extracted from the mandatory annual reports of district nurse (Ma-ternal and Child Health nurse, $\mathrm{MCH}$ nurse) responsible for primary maternal care from 
eleven district (micro-region) of Szabolcs-Szatmár-Bereg county. Information on the smoking status of expecting mothers, special care during pregnancy, pregnant women entering into maternity care after 28 weeks of pregnancy, borne women without district nurse care, were analyzed using Microsoft Excel Standard Normal Cumulative Distribution Function.

Results. The registered pregnant women's number was between 7000 and 7500 in the Szabolcs-Szatmár-Bereg county between 2010 and 2012. The standard normal cumulative distribution (SNCD) of pregnant women who is needing special care during pregnancy have examined significantly higher compared to the national average (standard data: 1,0) for three years in Szabolcs-Szatmár-Bereg county (2010: 1,66; 2011: 1,65; 2012: 1,56). Significantly higher the rates (SNCD) of the smoker pregnant women in Szabolcs-Szatmár-Bereg county (2010: 2,15; 2011: 2,09: 2012: 1,99) compared the national means (standard data: 1,0) in all three years. The ratio of pregnant women who were taken in care of an MCH nurse after the 28th week of the pregnancy was growing tendency in Szabolcs-Szatmár-Bereg county between 2010 and 2012 (2010:1,14; 2011:1,59; 2012: 1,64) and higher than national data (standard data: 1,0) but not significantly. The ratio (SNCD) of women having given birth without district nurse care in Szabolcs-Szatmár-Bereg county (2010: 1,37; 2011: 0,79; 2012: 1,55) was higher compared national proportions (standard data: 1,0 ) but these results not significant.

Discussion. Longitudinal surveys are needed to determine the relative contribution and roles played by individual and contextual characteristics in overall health. Such surveys should be a priority of federal and foundation funders. The examination shows the most important differences of analyzed indicators in Szabolcs-Szatmár Bereg county, and precipitate the quick start of the intervention.

Keywords: pregnant woman, Maternal-Child Health Services, smoking, health inequali-ties, Szabolcs-Szatmár-Bereg county

\section{Introduction}

The Hungarian population's opinion about their own health is rather poor in comparison with the European Union's (WHO 2016). The self-perceived health and healthy life years indicators ratio was lover in Hungary (EUROSTAT 2017a, EUROSTAT 2017b). There was a strong correlation between self-perceived health and life expectancy.

Different factors define the health conditions: the biological one predisposing to the illness (age and sex-related), the inherited factors and the lifestyle. Biological influences as include genetic expressions, prenatal influences, as well as biological constraints and possibilities created by prenatal and postnatal events plus prior states of health (NRC 2004). The harmful habits (e.g. smoking, alcohol and drug use, unhealthy diets, insufficient physical activity) will lead to the 
development of diseases, which collective occurrence multiplies the measure of the endangerment (EVSZ 2004, Horton 2009). Lifestyle and sociodemographic factors such as maternal education, poverty, smoking, alcohol and stress can influence birth outcomes namely through the maternal-foetal supply (Dejmek, Selevan, Sram 1996, Adres Day 2000).

David James Purslove Barker (MD, Ph.D., physician and researcher), Professor at the University of Southampton, made a novel observation in 1989. Namely, the lower birth weight of a child, the greater risk for coronary disease in adulthood(Barker Winter et al 1989, Barker Osmond 1986). This risk is increase gradient. Carrying on his researches he came to the conclusion that the low birth weight increases not only the coronary disease's risk, but also the diabetes mellitus type 2's, the hypertension's, and the stroke's risk in adulthood. This led to the theory of the foetal origins of some part of the adult diseases (Barker's theory). According to this, foetal origins of some part of the adult diseases (Ádány 2012). The persistent foetal malnutrition which is mainly maternally derived (nutrition, smoking habits, lifestyle) leads to the slow down of the fetus metabolism on the one hand, and these newborns come into the world with low birth weight (LBW <2500 g; intrauterine retardation, on the other hand. Adjust to the foetal malnutrition, intrauterine come into being a so-called "Thrifty phenotype" (Hales, Barker 2012) in the foetus, which results that such persons in their later adulthood, beside a normal amount of nutrient inputs, will be more prone to obesity and the development of the metabolic disease's risk factors (hypertension (Barker 2006, Eriksson, Forsén et al 2007), diabetes (Barker 1999), central obesity, high cholesterol level) (Barker 1997).

To this day, numerous amounts of research have demonstrated that the childhood health has an impact on the adult health status, moreover has an effect on its quality. Beyond this it is a more important statement, that the health of the pregnant woman and within this, her lifestyle, her eating habits and her harmful passions, like the smoking habit significantly determine the health conditions at birth, and the intrauterine foetal development, so the early childhood health quality (Fogarasi-Grenczer, Balázs 2012, Balázs, Rákóczi et al 2013). Thus, what kind of health we live and exist within our adulthood is totally traceable back to the gestational status before the conception, and during the pregnancy.

The district nurse (who be at work in primary care) supplies the pregnant women in Hungary. The pregnant women's care is written down in a measure (26/2014. (IV. 8.) EMMI order 2014).

The aim of this study is to describe that the indicators, concerning the lifestyle of the pregnant women and their health conditions, how influenced the health of the newborns and the early childhood development in the past decade in Hungary. Our objective was to describe changes in the health status of preg- 
nant women at the national and Szabolcs-Szatmár-Bereg county level during the period of 2010-2012.

\section{Methods}

The analysis based on indicators concerning the Hungarian pregnant women which were reported by district nurses annually (EMMI 2009). The county aggregated raw data with the assistance of the Pharmaceutical and health care quality and organizational development Institute (GYEMSZI) between 2006 to 2012 (AEEK 2017). These reports contain information about the Hungarian pregnant women in Szabolcs-Szatmár Bereg county.

Each pregnant mother's (person in Hungary: 2010: 122820; 2011: 125620, 2012: 120051), who have been recently taken to pregnant nursing, parameters were processed to the annual reports. The examined parameters were processed into the research from 2010 to 2012.

\section{The following indicators were introduced in the publication:}

Maternal indicators from eleven district (micro-region) of Szabolcs-SzatmárBereg county:

- The number of pregnant women registered during the year by district $(\mathrm{MCH})$ nurse,

- The ratio and number of pregnant women who is needing special care during pregnancy by district $(\mathrm{MCH})$ nurse,

- The ratio and number of umber of smoking pregnant women registered by district $(\mathrm{MCH})$ nurse,

- The ratio and number of pregnant women who were taken in care of an $\mathrm{MCH}$ nurse after the 28th week of the pregnancy,

- The ratio and number of the number of women having given birth without district nurse care.

After the data has been prepared and purged of the county layered, descriptive study, time series analysis. The maternal indicators description of its regional Szabolcs-Szatmár-Bereg county distribution and its comparison with the national average for 3 years was also part of the research. The evaluation of the regional differences and the analysis proceeded were used on standardisation founding (intensity ratios) with the Microsoft Office Excel 2007 programs. 
Excel NORMSDIST function calculates the Standard Normal Cumulative Distribution Function for a supplied value. The distribution has a mean of 0 (zero) and a standard deviation of one. To use analyses table with a non-standard normal distribution (either the location parameter is not 0 or the scale parameter is not 1), standardized this value by subtracting the mean and dividing the result by the standard deviation. Then look up the value for this standardized value. Specifically numbers that we are used in significance tests $p=0,975, Z p+1.960$. These are critical values for the normal distribution.

\section{Results}

\section{Number of pregnant women}

The registered pregnant women's number was between 120.000 and 126.000 in Hungary between 2010 and 2012. The data shows the pregnant women's number descending in a mild measure (person in Hungary: 2010: 122820; 2011: 125620, 2012:120051). The number of pregnant women registered during the year by MCH nurse was increase in Szabolcs-Szatmár-Bereg county between 2010 and 2012 (2010: 5,83\%, 2011: 5,77\% ratio in the total sample, 2012: not available correct data (Moravcsik-Kornyicki, Daragó, Kósa 2014).

\section{Pregnant women who is needing special care}

The standard normal cumulative distribution (SNCD) of pregnant women who is needing special care during pregnancy have examined significantly higher (2010: 1,66; 2011: 1,65; 2012: 1,56) compared to the standard data (national mean) for three years in Szabolcs-Szatmár-Bereg county.

The data shows that the eleven district (micro-region) effect matched with national means (standard data) significantly elevated every micro-region for three examined years. Based on the result can be related that SNCD of Nyírbátor micro-region was worst possible because significantly twofold higher (2010: $2,04 ; 2011: 1,98 ; 2012: 1,95)$ compared to the national average. (Table 1.) 


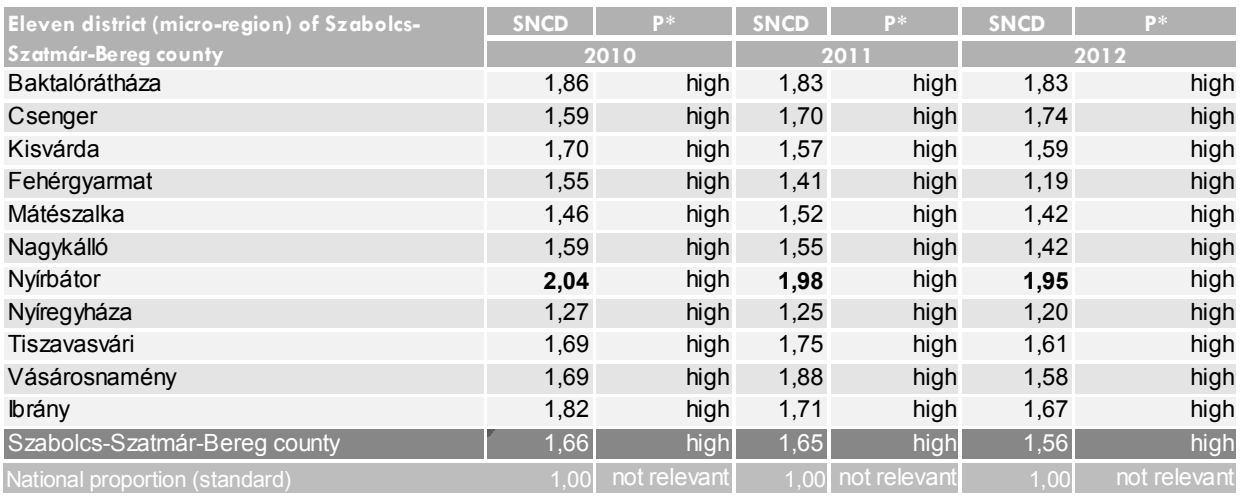

SNCD: standard normal cumulative distribution (standard value: national proportion; $1,0)$

* $\mathrm{p}>0,975(\mathrm{Zp}+1.960)$ and the $\mathrm{SNCD}<1,0$ : the value is significant, designated "law". $\mathrm{p}>0,975(\mathrm{Zp}+1.960)$ and the SNCD $>1,0$ : the value is significant, designated "high". $\mathrm{p}<0,975(\mathrm{Zp}+1.960)$ and the $\mathrm{SNCD}>/<1,0$ : the value is not significant, designated "ordinary".

Table 1. Standard normal cumulative distribution of pregnant women who is need special care in Szabolcs-Szatmár Bereg county between 2010 and 2012.

\section{Smoking pregnant women}

Having examined the ratio (SNCD) of smoking pregnant women registered by district $(\mathrm{MCH})$ nurse in the three analyzed years the trend was a micro-regional difference appears. Significantly higher the rates of the smoker pregnant women in Szabolcs-Szatmár-Bereg county (2010: 2,15; 2011: 2,09: 2012: 1,99) compared the national means (standard data) in all three years. The ratio of the smoker pregnant more favourable compared to the national average (standard data) for three years in Nyíregyháza micro-regional (2010: 0,69; 2011: 0,60; 2012: 0,66- this result was significant) of Szabolcs-Szatmár-Bereg county. Data shows not significant differed the in examined data of Nagykálló district in 2012 (SNCD: 0,93). (Table 2.) 


\begin{tabular}{|c|c|c|c|c|c|c|}
\hline \multirow{2}{*}{$\begin{array}{l}\text { Eleven district (micro-region) of Szaboles- } \\
\text { Szatmór Bereg county }\end{array}$} & SNCD & p* & SNCD & p* & SNCD & $\mathbf{p}^{*}$ \\
\hline & \multicolumn{2}{|c|}{2010} & \multicolumn{2}{|c|}{2011} & \multicolumn{2}{|c|}{2012} \\
\hline Baktalórátháza & 2,19 & high & 1,83 & high & 1,86 & high \\
\hline Csenger & 2,40 & high & 2,60 & high & 2,55 & high \\
\hline Kisvárda & 1,89 & high & 2,12 & high & 2,01 & high \\
\hline Fehérgyarmat & 2,47 & high & 2,35 & high & 1,98 & high \\
\hline Mátészalka & 2,25 & high & 2,45 & high & 2,30 & high \\
\hline Nagykálló & 1,18 & high & 1,17 & high & 0,93 & ordinary \\
\hline Nyírbátor & 2,72 & high & 2,18 & high & 2,23 & high \\
\hline Nyíregyháza & 0,69 & low & 0,60 & low & 0,66 & low \\
\hline Tiszavasvári & 2,12 & high & 2,60 & high & 2,28 & high \\
\hline Vásárosnamény & 3,37 & high & 2,91 & high & 2,83 & high \\
\hline lbrány & 2,43 & high & 2,24 & high & 2,22 & high \\
\hline Szabolcs-Szatmár-Bereg county & 2,15 & high & 2,09 & high & 1,99 & high \\
\hline National proportion (standard) & 1,00 & not relevant & 1,00 & not relevant & 1,00 & not relevant \\
\hline
\end{tabular}

SNCD: standard normal cumulative distribution (standard value: national proportion; $1,0)$

$* \mathrm{p}>0,975(\mathrm{Zp}+1.960)$ and the $\mathrm{SNCD}<1,0$ : the value is significant, designated "law". $\mathrm{p}>0,975(\mathrm{Zp}+1.960)$ and the SNCD $>1,0$ : the value is significant, designated "high".

$\mathrm{p}<0,975(\mathrm{Zp}+1.960)$ and the $\mathrm{SNCD}>/<1,0$ : the value is not significant, designated "ordinary".

Table 2. Standard normal cumulative distribution of smoking pregnant women registered by district (MCH) nurse in Szabolcs-Szatmár Bereg county between 2010 and 2012.

\section{Pregnant women entering into maternity care after 28 weeks of pregnancy}

The ratio of pregnant women who were taken in care of an $\mathrm{MCH}$ nurse after the 28 th week of the pregnancy, we find similar micro regional trend in SzabolcsSzatmár-Bereg county. The examined indicator (SNCD) was growing tendency in Szabolcs-Szatmár-Bereg county between 2010 and 2012 (2010:1,14; 2011:1,59; 2012: 1,64) and higher than national data (standard data) but not significantly. This data appeared departure (time and regional) in the eleven micro-region. The proportion (SNCD) of them higher in the Kisvárda (2010: 1,70; 2011: 2,04; 2012: 1,78), Fehérgyarmat (2010: 2,38; 2011: 1,53; 2012: 2,98), Mátészalka (2010: 1,26; 2011: 1,22; 2012: 1,23) and Vásárosnamény (2010: 1,28; 2011: 1,70; 2012: 1,95) micro-region in relation to the national average (standard data) in all three years but this results - not in all cases- significant. (Table 3.) 


\begin{tabular}{|c|c|c|c|c|c|c|}
\hline \multirow{2}{*}{$\begin{array}{l}\text { Eleven district (micro-region) of Szaboles- } \\
\text { Szatmár Bereg county }\end{array}$} & SNCD & p* & SNCD & p* & SNCD & p* \\
\hline & \multicolumn{2}{|c|}{2010} & \multicolumn{2}{|c|}{2011} & \multicolumn{2}{|c|}{2012} \\
\hline Baktalórátháza & 0,50 & ordinary & 2,28 & high & 1,59 & ordinary \\
\hline Csenger & 0,59 & ordinary & 3,32 & high & 2,00 & ordinary \\
\hline Kisvárda & 1,70 & ordinary & 2,04 & high & 1,78 & high \\
\hline Fehérgyarmat & 2,38 & high & 1,53 & ordinary & 2,98 & high \\
\hline Mátészalka & 1,26 & ordinary & 1,22 & ordinary & 1,23 & ordinary \\
\hline Nagykálló & 0,65 & ordinary & 1,91 & ordinary & 1,06 & ordinary \\
\hline Nyírbátor & 0,90 & ordinary & 0,98 & ordinary & 1,92 & high \\
\hline Nyíregyháza & 0,66 & ordinary & 0,82 & ordinary & 1,25 & ordinary \\
\hline Tiszavasvári & 1,35 & ordinary & 0,64 & ordinary & 1,56 & ordinary \\
\hline Vásárosnamény & 1,28 & ordinary & 1,70 & ordinary & 1,95 & ordinary \\
\hline lbrány & 1,28 & ordinary & 1,05 & ordinary & 0,69 & ordinary \\
\hline Szabolcs-Szatmár-Bereg county & 1,14 & ordinary & 1,59 & ordinary & 1,64 & ordinary \\
\hline National proportion (standard) & 1,00 & not relevant & 1,00 & not relevant & 1,00 & not relevant \\
\hline
\end{tabular}

SNCD: standard normal cumulative distribution (standard value: national proportion; $1,0)$

$* \mathrm{p}>0,975(\mathrm{Zp}+1.960)$ and the $\mathrm{SNCD}<1,0$ : the value is significant, designated "law". $\mathrm{p}>0,975(\mathrm{Zp}+1.960)$ and the SNCD $>1,0$ : the value is significant, designated "high". $\mathrm{p}<0,975(\mathrm{Zp}+1.960)$ and the $\mathrm{SNCD}>/<1,0$ : the value is not significant, designated "ordinary".

Table 3. Standard normal cumulative distribution of pregnant women who were taken in care of an MCH nurse after the 28th week of the pregnancy in Szabolcs-Szatmár Bereg county between 2010 and 2012 .

\section{Women having given birth without district nurse care}

The ratio (SNCD) of women having given birth without district nurse care in Szabolcs-Szatmár-Bereg county (2010: 1,37; 2011: 0,79; 2012: 1,55) was higher compared national proportions (standard data) but these results not significant. Significantly higher the rates was Kisvárda (2010: 2,57) and Fehérgyarmat (2010: 2,57) micro-region of Szabolcs-Szatmár-Bereg county. (Table 4.) 


\begin{tabular}{|c|c|c|c|c|c|c|}
\hline \multirow{2}{*}{$\begin{array}{l}\text { Eleven district (micro-region) of Szaboles- } \\
\text { Szatmár Bereg county }\end{array}$} & SNCD & szign & SNCD & szign & SNCD & szign \\
\hline & \multicolumn{2}{|c|}{2010} & \multicolumn{2}{|c|}{2011} & \multicolumn{2}{|c|}{2012} \\
\hline Baktalórátháza & 0,97 & ordinary & 0,51 & ordinary & 1,57 & ordinary \\
\hline Csenger & 1,26 & ordinary & 0,00 & ordinary & 3,22 & ordinary \\
\hline Kisvárda & 2,57 & high & 1,62 & ordinary & 0,47 & ordinary \\
\hline Fehérgyarmat & 2,64 & high & 0,85 & ordinary & 1,12 & ordinary \\
\hline Mátészalka & 1,34 & ordinary & 0,48 & ordinary & 1,44 & ordinary \\
\hline Nagykálló & 0,85 & ordinary & 0,82 & ordinary & 1,69 & ordinary \\
\hline Nyírbátor & 1,14 & ordinary & 1,62 & ordinary & 1,95 & ordinary \\
\hline Nyíregyháza & 1,62 & ordinary & 0,86 & ordinary & 0,47 & ordinary \\
\hline Tiszavasvári & 0,86 & ordinary & 0,89 & ordinary & 1,47 & ordinary \\
\hline Vásárosnamény & 1,04 & ordinary & 1,04 & ordinary & 1,46 & ordinary \\
\hline lbrány & 0,75 & ordinary & 0,00 & ordinary & 2,19 & ordinary \\
\hline Szabolcs-Szatmár-Bereg county & 1,37 & ordinary & 0,79 & ordinary & 1,55 & ordinary \\
\hline National proportion (standard) & 1,00 & not relevant & 1,00 & not relevant & 1,00 & not relevant \\
\hline
\end{tabular}

SNCD: standard normal cumulative distribution (standard value: national proportion; $1,0)$

$* \mathrm{p}>0,975(\mathrm{Zp}+1.960)$ and the $\mathrm{SNCD}<1,0$ : the value is significant, designated "law". $\mathrm{p}>0,975(\mathrm{Zp}+1.960)$ and the SNCD $>1,0$ : the value is significant, designated "high". $\mathrm{p}<0,975(\mathrm{Zp}+1.960)$ and the $\mathrm{SNCD}>/<1,0$ : the value is not significant, designated "ordinary".

Table 4. Standard normal cumulative distribution of pregnant women having given birth without district nurse care in Szabolcs-Szatmár Bereg county between 2010 and 2012.

\section{Discussion}

To sum it up, between 2010 and 2012, the data, reflecting the maternal conditions and healthy development, did not improve in the past decade. The topic are theoretical and practical too, therefore monitoring the health status of populations is essential to good health policy decisions. This is particularly true in maternal and child health (Magyar Kormány 2016) where targeted and timely interventions may have long-term consequences.

The result, that getting late into care (after the 28th. pregnancy week) and being left out from pregnant care are even stronger determinants than the pregnant smoking, is support the importance of begun care at the right time, and draw attention to the related domestic matters.

During the care the aim is that the pregnant women are included into care as soon as possible. The prenatal care has well developed institutional system with great traditions, as well as well-trained specialists in Hungary. The number of pregnant women, who do not present themselves at the regionally competent district nurse before labour, should be reduced thus they are not included in the care. 
The standard normal cumulative distribution (SNCD) of pregnant women who is need special care during pregnancy have examined and the rates (SNCD) of the smoker pregnant women in Szabolcs-Szatmár-Bereg county significantly higher compared the national means in all three years. Based on the result can be related that SNCD of the smoker pregnant women of Nyírbátor micro-region was worst possible because significantly twofold higher compared to the national average.

The analysis of the data is reflected the fact well that the pregnant's smoking habits, the date of their admission to the pregnant care, or the complete lack of the care show county inequality, as there are big differences within the county and between the micro-regions too (Kornyicki, Kósa 2010), so it is necessary to intervene there first, where the results of the analysis, which carried out by county, justified this.

To improve the health status of the pregnant women, effective steps should be taken as soon as possible, not only on territorial, but also on local level.

The health inequalities exam it is necessary to take it into consideration one third variable, this is the income situation this is attached to the reason effect in measure, and influences it, (Csizmadia 2016).

The more detailed exploration of those pregnant women's demographic feature, who late have been taken to pregnant nursing, who did not receive care or who smoke could be the object of further research, especially with regard to such pregnant women's financial situation, qualification, and social support. Because it is known that the smoking and the late or insufficient use of the health services -the above mentioned maternal factors, which critically affecting the intrauterine development - are more likely occur among groups with low socio-economic status (Balázs, Rákóczi et al 2013, Kósa, Lénárt, Ádány 2002, Kósa, Széles et al 2008).

It would be justified to define more precisely the inequalities according to the micro-regions data collection and analysis.

The health conditions of the pregnant women fall sort to the national average in some countries. A rapid and effective intervention is required to reverse this trend, because the significant improvement of the future adult generation's health should be a priority of the country.

\section{Acknowledgement}

This research was supported by the European Union and the State of Hungary, co-financed by the European Social Fund in the framework of TÁMOP 4.2.4. A/2-11-1-2012-0001 'National Excellence Program' 


\section{References}

1. AEEK (Állami Egészségügyi Ellátó Központ) Adatelemzési és Feldolgozási Csoport /korábban: GYEMSZI Minőségügyi Főosztály Informatika/ Szekszárd. Available at: http://193.225.50.35/webgy/regbe/belepes.php (12. 01. 2017. date last accessed)

2. Andres RL, Day MC. Perinatal complications associated with maternal tobacco use. Semin Neonatol. 2000;5(3):231-241.

3. Ádány R.: Megelőző orvostan és népegészségtan [Preventive Medicine and Public Health] Medicina Kiadó, Budapest 2012.

4. Balázs P., Rákóczi I., Grenczer A., Foley K.L. Risk factors of preterm birth and low birth weight babies among Roma and non-Roma mothers: a population-based study. Eur J Public Health. 2013;23(3):480-485.

5. Barker DJ. Maternal nutrition, fetal nutrition, and disease in later life. Nutrition. 1997 Sep;13(9):807-13.

6. Barker DJ. The fetal origins of type 2 diabetes mellitus. Ann Intern Med. 1999 Feb 16;130(4 Pt 1):322-4.

7. Barker DJ. Birth weight and hypertension. Hypertension. 2006 Sep;48(3):357-8. Epub 2006 Jul 31.

8. Barker DJ, Osmond C. Infant mortality, childhood nutrition, and ischaemic heart disease in England and Wales. Lancet. 1986 May 10;1(8489):1077-81.

9. Barker DJ, Winter PD, Osmond C, Margetts B, Simmonds SJ. Weight in infancy and death from ischaemic heart disease. Lancet. 1989 Sep 9;2(8663):577-80.

10. Csizmadia P.: Az egészségegyenlőtlenségek csökkentésének nehézségei. [Problems in reducing health inegualities] Egészségfejlesztés, 2017;58(1):21-29.

11. Dejmek J, Selevan SG, Sram RJ. The environment, life style and pregnancy outcome. Cas Lek Cesk. 1996;135:510-5.

12. Egészségügyi Világszervezet (EVSZ): Globális program az egészségfejlesztés hatékonyságáról. [Global Programme on Health Promotion Effectiveness (GPHPE)] 2004

Available at: http:/www.who.int/healthpromotion/areas/gphpe/en/ (20.01.2017. date last accessed)

13. Eriksson JG1, Forsén TJ, Kajantie E, Osmond C, Barker DJ. Childhood growth and hypertension in later life. Hypertension. 2007 Jun;49(6):141521. Epub 2007 Apr 23.

14. EMMI: Védőnői Jelentés adatlap. [reported by district nurses annually] 2009. Available at: http://193.225.50.35/dokumentum/Agazati_2009/R1003-09 v2_090801_Vedonoi_Jelentes_adatlap.pdf (12.01.2017. date last accessed) 
15. European Commission: European Statistics (EUROSTAT), 2017. Available at: http://ec.europa.eu/eurostat/web/health/statistics-illustrated (20.01.2017. date last accessed)

16. European Commission: European Statistics (EUROSTAT): Quality of life in Europe - facts and views - health Available at: http://ec.europa.eu /eurostat/ statistics-explained/ index.php/ Quality_of_life _in _Europe_facts_and_views_-_health (20.01.2017. date last accessed)

17. Fogarasi-Grenczer A., Balázs P. A dohányzás és a környezeti dohányfüstártalom kapcsolata a koraszülésekkel. [The correlation between smoking, environmental tobacco smoke and preterm birth] Orv Hetilap. 2012 ;153(18):690-694. doi: 10.1556/OH.2012.29325.

18. Hales CN, Barker DJ. The thrifty phenotype hypothesis. Br Med Bull. 2001;60:5-20.

19. World Health Organization Regional Office for Europe, European health for all database (HFA-DB), 2016.

20. Horton E.S.: Effects of lifestyle changes to reduce risks of diabetes and associated cardiovascular risks: results from large scale efficacy trials. Obesity, 2009;17 Suppl 3:S43-48.

21. Kornyicki Á, Kósa K: A várandós nők jellemzői országosan és régiónként 2006 és 2008 között., Népegészségügy. 2010; 88:(1) pp. 50-54.

22. Kósa K., Lénárt B., Ádány R. A cigány lakosság egészségi állapota. Orvosi Hetilap. 2002;143(43):2419-2426.

23. Kósa, Zs., Széles, Gy., Kardos, L., Kósa, K., Németh, R., Országh, S., Fésüs, G., McKee, M., Ádány, R. Vokó, Z. A telepszerü körülmények közt élők összehasonlító egészségfelmérése. Népegészségügy. 2008. 86(1):5-14.

24. Magyar Kormány: A Kormány 1886/2016. (XII. 28.) Korm. határozataaz „Egészséges Magyarország 2014-2020” Egészségügyi Ágazati Stratégia 2017-2018 évekre vonatkozócselekvési tervéről. Magyarközlöny; 2016; 219 : Available at: http:/www.kormany.hu/ download/5/23/ f0000/Eg\%C3\% A9 szs \%C3\%A9ges\%20Magyarorsz\%C3\%A1g\%202014\%E2\%80\%932020\%2 0Magyar\%20K\%C3\%B6zl\%C3\%B6ny.pdf (31.03.2017. date last accessed)

25. Moravcsik-Kornyicki Ágota, Daragó László, Kósa Karolina. Egészségügyi adatok minőségbiztosítása: jogszabályi kötelezettség vagy eszköz a társadalmi fejlődés elősegítésére. [ Quality assurance of health data: legislative obligation or asset in the promotion of social development] DEMOGRÁFIA. 2014; 57:(2-3)pp. 213-225.

26. National Research Council and Institute of Medicine of the National Academies: Children's Health, the Nation's wealth (assessing and improving child health), THE NATIONAL ACADEMIES PRESS, Washington, D.C.

27. 26/2014. (IV. 8.) EMMI rendelet - a várandósgondozásról. 


\section{Correspondence author:}

Ágota Moravcsik-Kornyicki

University of Debrecen Faculty of Health

Department of Health Methodology and Public Health

2-4. Sóstói Street, Nyíregyháza, Hungary

Phone: +36 $42404411 / 78186$

Fax: +3642408656

E-mail: kornyicki.agota@foh.unideb.hu;

\section{Moravcsik-Kornyicki Ágota:}

A szerző 1986. október 12-én született Kárpátalján. Jelenleg a Debreceni Egyetem Egészségügyi Kar, Védőnői Módszertani és Népegészségtani Tanszék tanársegédje. 2008-ban védőnői, 2010-ben okleveles népegészségügyi szakember egészségfejlesztési szakirányú diplomát szerzett. A Debreceni Egyetem Egészségtudományok Doktori Iskola abszolutóriumot szerzett doktorjelöltje. Kutatási területe: A sérülékeny csoportok (várandósok, gyermekek, romák) egészségi állapotának vizsgálata.

\section{Dr. Kósa Zsigmond}

Főiskolai tanár, a Debreceni Egyetem Egészségügyi Kar, Védőnői Módszertani és Népegészségtani Tanszék tanszékvezetője. Kutatási területe: A halandóság területi különbségeinek vizsgálata, morbiditási adatgyüjtési program kidolgozása, a telepszerü körülmények között élők egészségmagatartása, a telepszerü körülmények között élő iskoláskorúak egészségmagatartása, a bevándorlók egészségügyi ellátása. A Debreceni Egyetem Egészségtudományok Doktori Iskolájának akkreditált témavezetője.

\section{Jávorné Dr. Erdei Renáta}

A Debreceni Egyetem Egészségügyi Kar, Védőnői Módszertani és Népegészségtani Tanszék adjunktusa. Kutatási területe: Életminőség, szubjektív egészség, egészségmagatartás, egészség és egészségegyenlőtlenség vizsgálata.

\section{Gyulai Anikó}

A Debreceni Egyetem Egészségügyi Kar, Védőnői Módszertani és Népegészségtani Tanszék tanársegédje. Kutatási területe: Méhnyakszürés hatékonyságának növelése, méhnyakrák megelőzés, telepszerü körülmények között élö gyermekek egészségmagatartása, életmódja.

\section{Dr. János Sándor}

Egyetemi docens, a Debreceni Egyetem Népegészségügyi Kar, Biostatisztikai és Epidemiológiai Tanszék tanszékvezetője. Kutatási területe: Nem fertőző beteg- 
ségek etiológiáját, prevencióját, ellátás-hatékonyságát értékelő elsősorban ritka betegségekkel és területi különbségekkel kapcsolatos epidemiológiai, monitorozás jellegú vizsgálatok. A Debreceni Egyetem Egészségtudományok Doktori Iskolájának törzstagja.

\section{Dr. Kósa Karolina}

Egyetemi docens, a Debreceni Egyetem Népegészségügyi Kar Magatartástudományi Intézetének intézetigazgatója, a Debreceni Egyetem Népegészségügyi Karának stratégiai dékánhelyettese. Kutatási területe: Az egészség egyéni és kontextuális determinánsai; egészségi egyenlötlenségek, kisebbségek egészségi állapota, fiatalok egészsége és magatartása. A Debreceni Egyetem Egészségtudományok Doktori Iskolájának törzstagja. 